Vol. 1 No. 2 Desember 2021, e-ISSN : 2807-8667| p-ISSN : 2807-8837

\title{
EFEKTIFITAS DISCOVERY LEARNING UNTUK MENINGKATKAN HASIL BELAJAR PRODUK KREATITIF DAN KEWIRAUSAHAAN PESERTA DIDIK KELAS XII. TKJ SMK NEGERI I PEMALANG
}

\author{
KARNOTO \\ SMK Negeri 1 Pemalang \\ Email : karnoto.se@gmail.com
}

\begin{abstract}
ABSTRAK
Penelitian ini merupakan penelitian tindakan kelas. Penelitian ini bertujuan untuk memperbaiki proses pembelajaran dan meningkatkan hasil belajar Produk Kreatif dan Kewirausahaan dengan menerapkan model Discovery Learning. Subjek penelitian ini adalah Peserta Didikkelas XII TKJ 3 SMK Negeri 1 Pemalang semester genap tahun pelajaran 2020/2021 yang terdiri dari 17 Peserta Didiklaki-laki dan 19 Peserta Didikperempuan. Pada pelaksanaan proses pembelajaran sebelum dilakukan tindakan, terdapat permasalahan yaitu pembelajaran masih berpusat pada guru sehingga Peserta Didiktidak mampu menemukan konsep dari materi yang dipelajari. Untuk mengatasi permasalahan tersebut diperlukan suatu model pembelajaran dimana Peserta Didikdapat secara aktif menemukan sendiri konsep yang dipelajari. Instrumen pengumpulan data dalam penelitian ini adalah lembar pengamatan dan tes hasil belajar Produk Kreatif dan Kewirausahaan. Lembar pengamatan dianalisis secara deskriptif naratif, sedangkan tes hasil belajar Produk Kreatif dan Kewirausahaan dianalisis secara statistik deskriptif. Dari analisis terlihat bahwa terjadi perbaikan proses pembelajaran dari sebelum tindakan ke siklus I dan siklus II dan peningkatkan hasil belajar Produk Kreatif dan Kewirausahaan Peserta Didikkelas XII TKJ 3 SMK Negeri 1 Pemalang pada semester genap tahun pelajaran 2020/2021.
\end{abstract}

Kata Kunci : Minat belajar, discovery learning

\section{ABSTRACT}

This research is a classroom action research. This study aims to improve the learning process and improve learning outcomes for Creative Products and Entrepreneurship by applying the Discovery Learning model. The subjects of this study were students of class XII TKJ 3 SMK Negeri 1 Pemalang in the even semester of the 2020/2021 school year which consisted of 17 male students and 19 female students. In the implementation of the learning process before taking action, there are problems, namely learning is still teacher-centered so that students are not able to find concepts from the material being studied. To overcome these problems, a learning model is needed where students can actively find their own concepts being studied. The data collection instruments in this study were observation sheets and learning outcomes tests for Creative Products and Entrepreneurship. The observation sheets were analyzed descriptively by narrative, while the test of learning outcomes for Creative Products and Entrepreneurship were analyzed descriptively. From the analysis, it can be seen that there was an improvement in the learning process from before the action to cycle I and cycle II and an increase in learning outcomes for Creative Products and Entrepreneurship for class XII TKJ 3 SMK Negeri 1 Pemalang students in the even semester of the 2020/2021 academic year.

Keywords: Interest in learning, discovery learning

\section{PENDAHULUAN}

Pendidikan merupakan proses mengembangkan potensi Peserta Didik secara menyeluruh sehingga potensi yang dimiliki bermanfaat dan membawa kemajuan dalam bidang pendidikan. Suasana belajar dan proses pembelajaran bertujuan agar peserta didik secara aktif mengembangkan potensi dirinya untuk memiliki kekuatan spiritual, keagamaan, pengendalian diri, kepribadian, keceradasan, akhlak mulia serta keterampilan yang diperlukan dirinya, masyarakat, bangsa dan negara. 
Fakta yang terjadi banyak kalangan Peserta Didik menganggap kegiatan belajar mengajar adalah aktivitas yang tidak menyenangkan. Duduk berjam-jam dengan mencurahkan perhatian dan pikiran pada satu pokok bahasan, baik yang sedah diceramahkan guru atau yang sedang dihadapinya di meja belajar, hampir selalu dirasakan sebagai beban bukan sebagai upaya aktif untuk memperoleh ilmu.

Implementasi Kurikulum 2013 menurut Permendikbud Nomor 22 Tahun 2016 tentang Standar Proses menggunakan model pembelajaran yang diharapkan dapat membentuk perilaku saintifik, sosial serta mengembangkan rasa keingintahuan.

Karena keharusan dunia pendidikan untuk mengerti keinginan pasar, pada kurikulum 2013 revisi 2017 dimunculkanlah mata pelajaran tambahan dimana mata pembelajaran ini lebih mengedepankan aspek kognitif, softskill dan hardskill dari peserta didik, yaitu mata pelajaran produk kreatif dan kewirausahaan (PKK) yang menggabungkan perkembangan teknologi dengan wirausaha. Yandriana (2013) menyatakan, "Dalam hidup dan berkehidupan manusia memerlukan sebuah pekerjaan sebagai kecakapan hidup agar dapat memenuhi kebutuhan hidupnya".

Melalui pembelajaran produk kreatif dan kewirausahaan Peserta Didik diharapkan dapat memahami sikap dan perilaku wirausahawan, menganalisis konsep desain/prototy produk barang dan jasa, menerapkan strategi teknik pemasaran serta membuat perencanaan bisnis

Dari hasil observasi awal pada kegiatan belajar mengajar mata pelajaran Produk Kreatif dan Kewirausahaan di kelas XII. TKJ 3 SMK Negeri 1 Pemalang yang dilakukan peneliti menemukan bahwa Peserta Didik mengalami hambatan dalam mempelajari Produk Kreatif dan Kewirausahaan. Setelah dilakukan observasi, hasil belajar Peserta Didik kelas XII. TKJ 3 yang belum tuntas mencapai 15 Peserta Didik $(41,67 \%)$ dari 36 Peserta Didik yang ada. Selain itu, model penilaian/assessment yang digunakan di SMK belum mampu menilai keberhasilan tujuan pembelajaran yang mampu mengukur sikap, minat, dan perilaku wirausaha secara utuh. Hal ini menyebabkan keberhasilan dari tujuan pembelajaran yang terkait dengan kemampuan kewirausahaan belum dapat diketahui secara pasti. Oleh karena itu, untuk mengatasi permasalahan tersebut perlu dikembangkan model pembelajaran berbasis projek pendidikan kewirausahaan yang mampu menumbuhkan prestasi belajar dalam bidang akademik yang mencakup aspek kognitif, afektif, dan psikomotorik. Selain itu, juga mampu menumbuhkan kemampuan kewirausahaan yang meliputi sikap, minat dan perilaku wirausaha

Peneliti berasumsi bahwa Peserta Didik yang hasil belajarnya masih belum tuntas tersebut dapat ditingkatkan dengan menerapkan model pembelajaran yang menarik dalam proses pembelajaran yang menggantikan model pembelajaran sebelumnya, Berupa model pembelajaran discovery learning sehingga dapat meningkat hasil belajar Peserta Didik dan tuntas sesuai KKM Produk Kreatif dan Kewirausahaan untuk kelas XII yang ada, yakni 75.

Model Discovery Learning adalah suatu model untuk mengembangkan cara belajar Peserta Didik aktif dengan menemukan sendiri, menyelediki sendiri, maka hasil yang diperoleh akan setia dan tahan lama dalam ingatan, tidak akan mudah dilupakan Peserta Didik (Hosnan, 2014). Ridwan Abdullah Sani (2013) menyatakan bahwa model Discovery Learning sesuai dengan teori Bruner yang menyarankan agar Peserta Didik belajar secara aktif untuk membangun konsep dan prinsip.

M. Hosnan (2014) menyatakan bahwa penerapan model Discovery Learning membuat Peserta Didik mengerti konsep dasar dan ide-ide lebih baik serta Peserta Didik dapat mentransfer pengetahuannya ke berbagai konteks. Sejalan dengan pendapat M. Hosnan, Bruner (dalam Dahar, 2010) menyatakan bahwa pengetahuan yang diperoleh dengan belajar penemuan menghasilkan pengetahuan yang benar-benar bermakna sehingga dapat memberikan hasil belajar penemuan yang mempunyai efek transfer yang lebih baik daripada hasil belajar lainnya. Penerapan model Discovery Learning yang mengarahkan Peserta Didik aktif untuk memperoleh pengetahuan sehingga materi pelajaran mengendap dalam pemikiran Peserta Didik, pengetahuan yang diperoleh bermakna, membuat peserta didikmengerti konsep dasar 
dan ide-ide lebih baik sertamempunyai efek transfer yang lebih baik daripada hasil belajar lainnya merupakan pemecahan permasalah di atas.

\section{METODE PENELITIAN}

Bentuk penelitian ini adalah Penelitian Tindakan Kelas Kolaboratif yang bekerjasama dengan guru Produk Kreatif dan Kewirausahaan yang mengajar di kelas XII TKJ SMK Negeri 1 Pemalang. Pelaksanaan penelitian ini mengikuti tahap-tahap PTK yang pelaksanaannya terdiri dari dua siklus, masing-masing siklus terdiri dari tiga kali pertemuan dan satu kali ulangan harian. Suharsimi Arikunto (2014) mengemukakan bahwa setiap siklus terdiri dari empat tahap (perencanaan, pelaksanaan, pengamatan, dan refleksi).

Tindakan yang dilakukan dalam proses pembelajaran di kelas pada penelitian ini adalah penerapan model Discovery Learning. Subjek penelitian ini adalah Peserta Didik kelas XII TKJ 3 SMK Negeri 1 Pemalang semester genap tahun ajaran 2020/2021 yang terdiri dari 12 orang Peserta Didik laki-laki dan 24 orang Peserta Didik perempuan. Instrumen penelitian ini adalah perangkat pembelajaran dan instrumen pengumpulan data. Perangkat pembelajaran terdiri dari silabus, rencana pelaksanaan pembelajaran (RPP) dan lembar aktivitas Peserta Didik (LAS). Instrumen pengumpul data terdiri dari lembar pengamatan dan perangkat tes hasil belajar Produk Kreatif dan Kewirausahaan. Lembar pengamatan digunakan untuk mendapatkan data tentang aktivitas guru dan Peserta Didik selama proses pembelajaran. Perangkat tes hasil belajar Produk Kreatif dan Kewirausahaan terdiri kisi-kisi dan soal Kuis I dan II. Tes hasil belajar Produk Kreatif dan Kewirausahaan digunakan untuk mengumpulkan data tentang hasil belajar Produk Kreatif dan Kewirausahaan Peserta Didik setelah menyelesaikan satu kompetensi dasar dengan proses pembelajaran menggunakan model Discovery Learning .

\section{HASIL DAN PEMBAHASAN}

\section{Hasil}

Pada siklus I dilaksanakan tiga kali pertemuan dan satu kali kuis. Dilakukan analisis terhadap aktivitas guru dan Peserta Didik melalui lembar pengamatan dan diskusi dengan pengamat. Berdasarkan lembar pengamatan dan diskusi dengan pengamat selama melakukan tindakan, terdapat beberapa kekurangan yang dilakukan guru dan Peserta Didik yaitu pada kegiatan awal, pada pertemuan pertama dan kedua guru tidak memberikan motivasi kepada Peserta Didik, Peserta Didik berebutan dan tidak teratur dalam menyampaikan pendapat. Terdapat kekurangan pada penyampaian pembagian kelompok secara lisan di pertemuan kedua sehingga Peserta Didik kesulitan menemukan anggota kelompoknya. Pada pertemuan kedua juga terdapat Peserta Didik yang tidak memperhatikan penyampaian informasi oleh peneliti. Terdapat kemajuan pada pertemuan kedua yaitu Peserta Didik mulai aktif pada saat menanggapi hasil diskusi kelompok. Pada pertemuan ketiga, penyampaian motivasi telah terlaksana. Untuk menghindari Peserta Didik kesulitan menemukan anggota kelompoknya maka peneliti menayangkan pembagian kelompok pada pertemuan ketiga. Peserta Didik juga mulai menyampaikan jawaban atau pendapat secara teratur serta memperhatikan penyampaian informasi oleh peneliti.

Pada kegiatan inti, aktivitas peneliti dan Peserta Didik semakin membaik pada setiap pertemuannya. Pada pertemuan pertama dan kedua, saat Peserta Didik mengerjakan LAS, Peserta Didik mengalami kesulitan pada tahap identifikasi masalah dalam merancang langkahlangkah penyelesaian dan merumuskan jawaban sementara atau hipotesis. Peneliti membantu mengarahkan Peserta Didik dengan mengaitkan apresepsi yang telah diberikan untuk merancang langkah-langkah penyelesaian dan merumuskan jawaban sementara atau hipotesis. Pada pertemuan ketiga dan seterusnya Peserta Didik bersama kelompoknya mampu merancang langkah-langkah penyelesaian dan merumuskan jawaban sementara tanpa arahan dari peneliti. Terdapat anggota kelompok yang pada awal mengerjakan LAS-1 tidak bekerja bersama-sama. Peserta Didik kurang aktif pada saat menanggapi hasil diskusi. Pada pertemuan kedua, langkahlangkah pada LAS telah sesuai dengan alokasi waktu sehingga semua langkah pada LAS dapat 
dilaksanakan dan dikerjakan. Peserta Didik juga mulai aktif menanggapi hasil presentasi diskusi kelompok. Pada pertemuan ketiga, Peserta Didik dalam kelompok hanya memerlukan sedikit bimbingan untuk mengumpulkan data, mengolah data, membuktikan dan membuat kesimpulan hasil diskusi kelompok, tidak seperti pada pertemuan pertama dan kedua yang memerlukan lebih banyak bimbingan. Suasana kelas ketika berdiskusi sudah membaik. Peserta Didik berdiskusi dan bekerja sama dalam menemukan materi pelajaran dan menyelesaikan masalah yang diberikan. Peserta Didik juga lebih teratur dalam menyampaikan pendapat.

Pada kegiatan penutup, aktivitas peneliti dan Peserta Didik semakin membaik pada setiap pertemuannya. Pada pertemuan pertama, peneliti tidak melaksanakan tes formatif, melakukan refleksi dan pemberian umpan balik kepada Peserta Didik. Pada pertemuan kedua dan ketiga, setiap tahapan pada kegiatan penutup telah terlaksana sesuai rencana serta Peserta Didik juga mulai menyampaikan pendapat dan kesimpulan secara teratur dan tidak berebutan. Berdasarkan refleksi siklus 1, rencana yang dilakukan peneliti untuk memperbaiki tindakan adalah: (1) mengingatkan waktu proses pembelajaran, agar pelaksanaan setiap kegiatan pembelajaran dapat dilakukan sesuai perencanaan; dan (2) lebih memotivasi serta membimbing Peserta Didik terutama saat diskusi kelompok dan diskusi kelas.

Pada siklus II dilaksanakan tiga kali pertemuan dan satu kali kuis. Pada siklus kedua ini keterlaksanaan proses pembelajaran mengalami peningkatan bila dibandingkan pada siklus pertama. Keterlaksanaan pembelajaran pada siklus kedua ini sudah sesuai dengan langkahlangkah pembelajaran yang sudah direncanakan.

Ditinjau dari hasil belajar, peningkatan hasil belajar Peserta Didik dapat dilihat dari analisis ketercapaian ketercapaian KKM dan analisis KKM indicator. Analisis ketercapaian KKM diperoleh dengan melihat jumlah persentase Peserta Didik yang mencapai KKM pada skor dasar sebelum penerapan model Discovery Learning dan persentase jumlah Peserta Didik yang mencapai KKM pada tes hasil belajar dengan menerapkan model Discovery Learning. Dari 36 Peserta Didik kelas XII TKJ 3 Jumlah Peserta Didik yang mencapai KKM pada skor dasar adalah 15 orang ( 41,67\%). Kemudian pada Kuis I meningkat menjadi 23 orang (63,89\%) dan pada Kuis II meningkat menjadi 31 orang (86,11\%) pada KD 3.12 Menerapkan peroses produksi masal. Dari uraian tersebut, terlihat bahwa adanya peningkatan jumlah Peserta Didik yang mencapai KKM dari skor dasar ke Kuis I dan peningkatan Peserta Didik yang mencapai KKM dari Kuis I ke Kuis II.

Ketuntasan hasil belajar Produk Kreatif dan Kewirausahaan dari 36 Peserta Didik kelas XII TKJ 3 SMK Negeri 1 Pemalang dianalisis secara individu untuk setiap indikator soal. Jumlah Peserta Didik yang mencapai KKM untuk setiap indikator soal (mencapai nilai untuk setiap indikator soal) pada Kuis I dapat dilihat pada tabel 3 berikut:

Tabel 3 Persentase Ketercapaian KKM Indikator Pengetahuan pada Kuis-I

\begin{tabular}{|c|l|c|c|}
\hline No & \multicolumn{1}{|c|}{ Indikator Ketercapaian } & $\begin{array}{c}\text { Jumlah Peserta } \\
\text { Didikyang } \\
\text { Mencapai } \\
\text { KKM }\end{array}$ & $\begin{array}{c}\text { indikator } \\
\text { Presentase } \\
(\%)\end{array}$ \\
\hline 1 & $\begin{array}{l}\text { Menjelaskan tahapan peroses produksi } \\
\text { masal }\end{array}$ & 36 & $100 \%$ \\
\hline 2 & Mengidentifikasi peroses produksi masal & 23 & $63,89 \%$ \\
\hline
\end{tabular}

Berdasarkan Tabel 3 dapat dilihat bahwa persentase pencapaian KKM indikator terendah yaitu 50\% pada indikator 1 . Hal ini disebabkan karena terdapat 18 Peserta Didik yang mengalami kesalahan dalam mengidentifikasi peroses produksi. Kesalahan dalam mengidentifikasi yang dilakukan Peserta Didik menyebabkan peneliti lebih teliti mengamati dan membimbing Peserta Didik ketika mengkonstruksi sehingga Peserta Didik memiliki pemahaman yang benar pada siklus II. 
Jumlah Peserta Didik yang mencapai KKM dari 36 Peserta Didik kelas XII TKJ 3 SMK Negeri 1 Pemalang untuk setiap indikator pada kuis II dapat dilihat pada Tabel 4 berikut.

Tabel 4 Persentase Ketercapaian KKM Indikator pada Kuis-II

\begin{tabular}{|c|c|c|c|}
\hline No & Indikator Ketercapaian & $\begin{array}{c}\text { Jumlah Peserta } \\
\text { Didikyang } \\
\text { Mencapai } \\
\text { KKM }\end{array}$ & $\begin{array}{c}\text { indikator } \\
\text { Presentase } \\
(\%)\end{array}$ \\
\hline 1 & $\begin{array}{l}\text { Menerapkan metoda perakitan produk } \\
\text { barang/ jasa }\end{array}$ & 36 & $100 \%$ \\
\hline 2 & $\begin{array}{l}\text { Memahami metode perakitan produk } \\
\text { barang/ jasa }\end{array}$ & 31 & $86,11 \%$ \\
\hline
\end{tabular}

Dari tabel 4 dapat dilihat bahwa persentase ketercapaian KKM indikator pada siklus II, lebih baik dibandingkan dengan siklus I. Hal ini menunjukkan bahwa adanya peningkatan yang terjadi pada siklus II.

Berdasarkan analisis ketercapaian KKM indikator keterampilan dapat diketahui peningkatan hasil belajar Produk Kreatif dan Kewirausahaan peserta didik pada kompetensi keterampilan. Nilai keterampilan dikatakan berhasil apabila nilai mencapai KKM untuk nilai keterampilan, yaitu 75. Persentase ketercapaian KKM indikator keterampilan pada siklus pertama dapat dilihat pada Tabel 5.

Tabel 5 Persentase Ketercapaian KKM Indikator Keterampilan Siklus I

\begin{tabular}{|c|l|c|c|c|}
\hline \multirow{2}{*}{ No } & \multicolumn{1}{|c|}{ Indikator Ketercapaian } & $\begin{array}{c}\text { Nomor } \\
\text { Soal }\end{array}$ & $\begin{array}{c}\text { Jumlah } \\
\text { Peserta } \\
\text { Didikyang } \\
\text { Mencapai } \\
\text { KKM }\end{array}$ & $\begin{array}{c}\text { indikator } \\
\text { Presentase } \\
(\%)\end{array}$ \\
\hline \multirow{2}{*}{1} & $\begin{array}{l}\text { Menyusun indikator keberhasilan } \\
\text { tahapan produksi masal }\end{array}$ & 5 & 27 & $75 \%$ \\
\cline { 2 - 5 } 2 & Melakukan perencanaan roduk masal & 11 & 25 & $69,44 \%$ \\
\cline { 3 - 5 } & & 15 & 20 & $52,78 \%$ \\
\hline
\end{tabular}

Dari Tabel 5 tersebut dapat dilihat bahwa tidak semua Peserta Didik mencapai ketuntasan masing-masing indikator. Persentase ketercapaian KKM indikator 1 dan indikator 2 yang diperoleh masih di bawah $100 \%$. Karena masih ada Peserta Didik yang belum mencapai KKM indikator keterampilan, peneliti mengecek kriteria keterampilan yang dilakukan oleh Peserta Didik dalam menyelesaikan soal Kuis I.

Pada indikator 1 pencapaian persentase KKM Keterampilan Peserta Didik pada soal nomor 5 sebesar $75 \%$ sedangkan pada soal nomor 9 sebesar 69,44\%. Pada indikator 1 terdapat soal nomor 5 dan nomor 9. Pada soal nomor 1 diberikan soal rutin, Peserta Didik dapat menyelesaikan soal dengan terampil sedangkan pada soal nomor 5 Peserta Didik diberikan masalah bebentuk soal cerita. Peserta Didik kurang terampil dalam menyelesaikan masalah yang diberikan. Peserta Didik salah menentukan indikator untuk menyelesaikan masalah.

Pada indikator 2 pencapaian persentase KKM Keterampilan Peserta Didik pada soal nomor 11 sebesar 52,78\% sedangkan pada soal nomor 20 sebesar 55,56\%. Pada soal nomor 11 diberikan soal rutin, Peserta Didik terampil dalam menyelesaikan permasalahan sedangkan pada soal nomor 15 Peserta Didik diberikan masalah dalam bentuk soal cerita. Peserta Didik kurang terampil dalam menyelesaikan masalah dalam bentuk soal cerita. Dari kedua indikator tersebut dapat disimpulkan kurangnya keterampilan Peserta Didik dalam menyelesaikan masalah apabila diberikan masalah berbentuk soal cerita. 
Persentase ketercapaian KKM indikator keterampilan pada siklus II dapat dilihat pada Tabel 6.

Tabel 6 Persentase Ketercapaian KKM Indikator Keterampilan Siklus II

\begin{tabular}{|c|c|c|c|c|}
\hline No & Indikator Ketercapaian & $\begin{array}{c}\text { Nomor } \\
\text { Soal }\end{array}$ & $\begin{array}{c}\text { Jumlah } \\
\text { Peserta } \\
\text { Didikyang } \\
\text { Mencapai } \\
\text { KKM }\end{array}$ & $\begin{array}{c}\text { indikator } \\
\text { Presentase } \\
(\%)\end{array}$ \\
\hline \multirow{2}{*}{1} & \multirow{2}{*}{$\begin{array}{l}\text { Melakukan perakitan produk barang/ } \\
\text { jasa }\end{array}$} & 3 & 36 & $100 \%$ \\
\hline & & 5 & 36 & $100 \%$ \\
\hline \multirow[b]{2}{*}{2} & \multirow{2}{*}{$\begin{array}{l}\text { Melakukan pengujian produk barang/ } \\
\text { jasa }\end{array}$} & 7 & 31 & $86,11 \%$ \\
\hline & & 9 & 32 & $88,89 \%$ \\
\hline
\end{tabular}

Dari Tabel 6 tersebut dapat dilihat bahwa tidak semua Peserta Didik mencapai ketuntasan masing-masing indikator. Persentase ketercapaian KKM indikator yang diperoleh masih di bawah $100 \%$. Karena masih ada Peserta Didik yang belum mencapai KKM indikator keterampilan, peneliti mengecek kriteria keterampilan yang dilakukan oleh Peserta Didik dalam menyelesaikan soal Kuis II. Adapun analisa terhadap keterampilan Peserta Didik dalam menjawab soal yang diberikan akan diuraikan pada masing-masing indikator sebagai berikut.

Pada indikator 1 pencapaian persentase KKM Keterampilan Peserta Didik pada soal nomor 7 sebesar 86,11 \% sedangkan pada soal nomor 9 sebesar 88,89\%. Pada indikator 1 terdapat soal nomor 7 dan nomor 9 . Pada soal nomor 7 diberikan soal rutin, Peserta Didik dapat menyelesaikan soal dengan terampil sedangkan pada soal nomor 9 Peserta Didik diberikan masalah bebentuk soal cerita. Peserta Didik kurang terampil dalam menyelesaikan masalah yang diberikan. Peserta Didik salah menentukan rumus untuk menyelesaikan masalah.

Berdasarkan hasil analisis data, terjadi peningkatan hasil belajar Peserta Didik Dari hasil Kuis I dan Kuis II. Hasil tersebut dapat dilihat pada grafik 1 dan grafik 2.

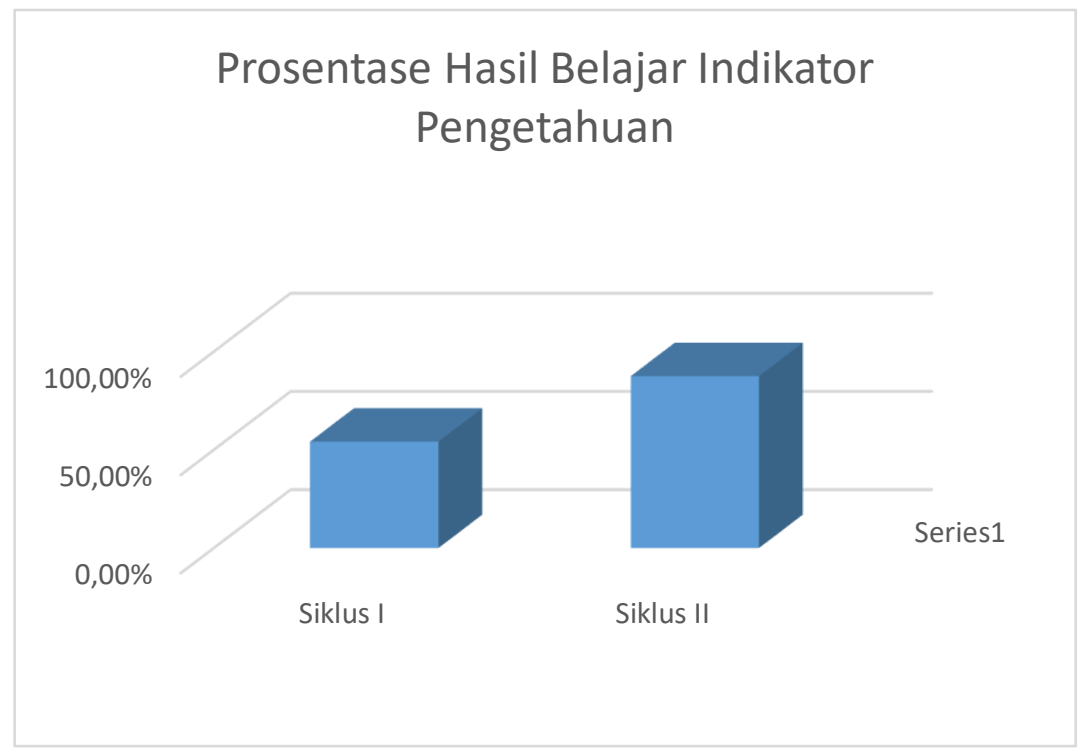

Gambar 1. Grafik Persentase Ketercapaian KKM Indikator Pengetahuan pada Kuis I dan II 


\section{Prosentase Hasil Belajar indikator Ketrampilan}

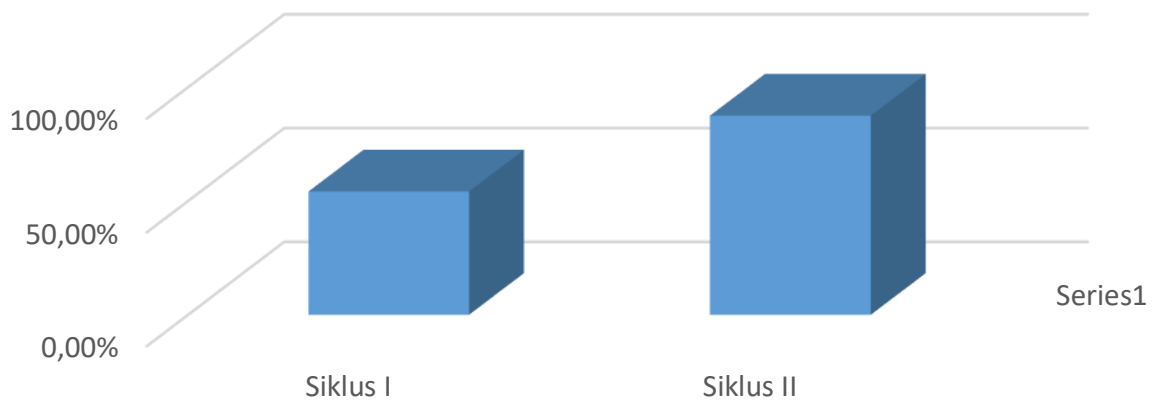

\section{Gambar 2. Grafik Persentase Ketercapaian KKM Indikator Ketrampilan pada Kuis I dan II}

Berdasarkan uraian tentang analisis aktivitas guru dan Peserta Didik, serta analisis peningkatan hasil belajar Peserta Didik dapat dikatakan bahwa terjadi perbaikan proses pembelajaran dan hasil belajar Peserta Didik meningkat sehingga hasil analisis penelitian tersebut mendukung hipotesis tindakan yang diajukan yaitu, jika diterapkannya model Discovery Learning maka dapat memperbaiki proses pembelajaran dan meningkatkan hasil belajar Produk Kreatif dan Kewirausahaan Peserta Didik kelas XII TKJ 3 SMK Negeri 1 Pemalang semester ganjil tahun pelajaran 2020/2021 pada KD 3.12 Menerapkan peroses produksi masal.

\section{Pembahasan}

Data hasil penelitian mengindikasikan profil hasil belajar Peserta Didik XII. TKJ 3 yang belum tuntas mencapai 15 Peserta Didik $(41,67 \%)$ dari 36 Peserta Didik yang ada, ini menunjukan bahwa mayoritas Peserta Didik belum tuntas. Hal ini menunjukkan bahwa hasil belajar Peserta Didik sampel penelitian belum mencapai tahap optimal dalam arti masih perlu ditingkatkan. Kemudian pada Kuis I meningkat menjadi 23 orang (63,89\%) dan pada Kuis II meningkat menjadi 31 orang $(86,11 \%)$. Dari uraian tersebut, terlihat bahwa adanya peningkatan jumlah Peserta Didik yang mencapai KKM dari skor dasar ke Kuis I dan peningkatan Peserta Didik yang mencapai KKM dari Kuis I ke Kuis II.

Keberhasilan pada peningkatan hasil belajar Peserta Didik dikarenakan penerapan model pembelajaran discovery learning yang dilakukan sesuai dalam sintak. Hamalik (Takdir,2012:29) Model discovery learning adalah suatu model untuk mengembangkan cara belajar Peserta Didik aktif dengan menemukan sendiri, menyelidiki sendiri, maka hasil yang diperoleh akan tahan lama dalam ingatan tidak akan mudah dilupakan Peserta Didik. Dengan belajar penemuan, Peserta Didik juga bisa berpikir analisis dan mencoba memecahkan sendiri masalah yang dihadapi. Disini Peserta Didik akan merasa tertantang untuk mengetahui proses percobaan, sehingga Peserta Didik merasa penasaran dan tertarik untuk memahami materi serta menguasai materi pembelajaran.

Berdasarkan pendapat Wahyudi \& Siswanti (2015), discovery learning merupakan pelajaran yang disajikan dengan tidak utuh untuk meningkatkan kemampuan penemuan pada siswa. Pendapat ini sejalan dengan pendapat Hanifah \& Wasitohadi (2017) bahwa discovery learning merupakan model pembelajaran yang mengajak Peserta Didik belajar aktif menemukan sendiri pengetahuannya, hal itu akan membuat Peserta Didik merasa tertantang dan tertarik untuk mengidentifikasi permasalahan dengan suatu percobaan, 
sehingga Peserta Didik akan merasa tertarik untuk memahai materi dan menguasai materi pembelajaran tematik.

Peneliti lain yang dapat membuktikan meningkatnya kemampuan berpikir kreatif dan hasil belajar Peserta Didik dengan menerapkan model discovery learning adalah Erik R. (2014). Kemampuan berpikir kreatif Peserta Didikmencapai ketuntasan dengan nilai ratarata 71,55. Hasil belajar Peserta Didikdapat dilihat dari hasil penelitian Mumin S dan Sri R (2017) yang menghasilkan, pada siklus I hasil belajar Peserta Didikmencapai persentase ketuntasan sebesar 54,6, sedangkan pada siklus II mencapai persentase ketuntasan sebesar $80,9 \%$, dan siklus III mencapai persentase ketuntasan sebesar 91,8\%.

\section{KESIMPULAN}

Berdasarkan hasil penelitian dan pembahasan dapat disimpulkan bahwa penerapan model Discovery Learning pada proses pembelajaran Produk Kreatif dan Kewirausahaan dapat memperbaiki proses pembelajaran dan meningkatkan hasil belajar Produk Kreatif dan Kewirausahaan Peserta Didik kelas XII TKJ 3 SMK Negeri 1 Pemalang semester ganjil tahun pelajaran 2020/2021 pada KD 3.12 Menerapkan peroses produksi masal.

Berdasarkan pembahasan dan kesimpulan dari penelitian ini, peneliti mengajukan beberapa rekomendasi dalam penerapan model Discovery Learning pada pembelajaran Produk Kreatif dan Kewirausahaan, diantaranya:

1. Penerapan model Discovery Learning dapat dijadikan salah satu alternatif model pembelajaran yang dapat diterapkan untuk memperbaiki proses pembelajaran dan meningkatkan hasil belajar Produk Kreatif dan Kewirausahaan peserta didik.

2. Dalam menyediakan sarana pembelajaran berupa LAS, sebaiknya guru/peneliti mencantumkan alokasi waktu pengerjaan LAS untuk setiap tahapan model Discovery Learning agar waktu yang telah direncanakan sesuai dengan pelaksanaan pembelajaran.

\section{DAFTAR PUSTAKA}

BSNP. 2014. Permendikbud Nomor 59 Tahun 2014 tentang Standar Proses Pendidikan Dasar Dan Menengah. Kemendikbud. Jakarta.

BSNP. 2016. Permendikbud No. 22 Tahun 2016 tentang Standar Isi untuk Satuan Pendidikan Dasar dan Menengah. Kemendibud. Jakarta.

BSNP. 2016. Permendikbud No. 23 Tahun 2016 tentang Standar Penilaian Pendidikan. Kemendibud. Jakarta.

Hanifah, U., \& Wasitohadi. (2017). Perbedaan efektivitas antara penerapan model pembelajaran discovery dan inquiry ditinjau dari hasil belajar IPA siswa. Jurnal Mitra Pendidikan, 1(2), 92-104.

M. Hosnan 2014. Pendekatan Saintifik dan Kontekstual dalam Pembelajaran Abad 21. Ghalia Indonesia. Bogor.

Railsback, J. 2002. Project-Based Instruction: Creating Excitement for Learning. Portland, OR: Northwest Regional Educational Laboratory. http://www.nwrel.org/request/2002aug/index.html*.

Ratna Wilis Dahar. 2010. Teori-Teori Belajar \& Pembelajaran. Erlangga. Jakarta.

Rusman. 2013. Model-model Pembelajaran Mengembangkan Profesionalisme Guru, Edisi Kedua. Depok: PT Rajagrafindo Persada. Edisi 2.

Suharsimi Arikunto, dkk. 2014. Penelitian Tindakan Kelas. Bumi Aksara. Jakarta. Sumarno. 1997. Pedoman Pelaksanaan Penelitian Tindakan Kelas (PTK). Dikti Depdikbud. Yogyakarta.

Suryana. 2006. Kewirausahaan Pedoman Praktis: Kiat dan Proses Menuju Sukses. Bandung: PT Salemba Empat.

Takdir. 2012. Pembelajaran Discovery Strategy dan Mental Vocational Skill. Jogjakarta :Diva Press 
Thomas, J.W. 1998. "Project-Based Learning: Overview". Novato, CA: Buck Institute for Education. Journal of Nursing Education. Vol. 38, Iss.8, pg. 340, 7 pgs.

Wahyudi, W., \& Siswanti, M. (2015). Pengaruh Pendekatan Saintifik Melalui Model Discovery Learning dengan Permainan Terhadap Hasil Belajar Matematika Siswa Kelas 5 SD. Scholaria: Jurnal Pendidikan Dan Kebudayaan, 5(3), 23-36. https://doi.org/10.24246/j. scholaria. 2015. v5.i3.p23-36

Winataputra, Udin S., dkk. 2008. Teori Belajar dan Pembelajaran. Universitas Terbuka. Jakarta. 